\title{
Nettside med virtuelt pasientrom forbereder studentene på praksis
}

Sykepleierstudenter i Tromsø og Hammerfest bruker nettsiden Praksisportalen når de skal forberede seg til praksisstudiene. I Praksisportalen får studentene blant annet møte en fiktiv pasient $i$ et virtuelt pasientrom.

\section{Forfattere}

\section{Catrine Buck Jensen}

Universitetslektor

Institutt for helse- og omsorgsfag, Det helsevitenskapelige fakultet, Universitetet i Troms $\varnothing$ -

Norges arktiske universitet

Jeanette Huemer

Førstelektor

Institutt for helse- og omsorgsfag, Helsevitenskapelige fakultet, Universitetet i Tromsø -

Norges arktiske universitet

Rigmor Furu

Førstelektor

Senter for helsefaglig pedagogisk utvikling, Helsevitenskapelige fakultet, Universitetet i

Tromsø - Norges arktiske universitet

Anita Iversen

Førsteamanuensis

Senter for helsefaglig pedagogisk utvikling, Helsevitenskapelige fakultet, Universitetet $\mathrm{i}$

Tromsø - Norges arktiske universitet

\section{Sykepleierutdanning Praksisstudie Pedagogikk Informasjonsteknologi}

Sykepleierstudent

Sykepleien 2019 107(75645)(e-75645)

DOI: https://doi.org/10.4220/Sykepleiens.2019.75645 


\section{Hovedbudskap}

Praksisportalen er en nettside som inneholder blant annet videoer, refleksjonsspørsmål og et virtuelt pasientrom. Sykepleierstudenter kan bruke Praksisportalen til å forberede seg til praksisstudiene. Nettsiden inneholder også informasjon for dem som skal veilede studentene når de er i praksis.

Etter fusjonen mellom Universitetet i Tromsø og Høgskolen i Finnmark i 2013 ble sykepleierutdanningen utvidet til flere campuser. Vårt prosjekt «Kvalitet i praksisstudier» har vært et samarbeid mellom personer i fagmiljøene hos campus Hammerfest og campus Tromsø.

Bakgrunnen for prosjektet var mangefasettert og prosjektet startet bredt ut. Vi ville styrke kommunikasjonen mellom utdanningsstedet og praksisstedet. Også nødvendigheten av å bedre overgangen fra teoriundervisning til praksisstudier for både studenter og praksisveiledere sto sterkt. Videre var det ønskelig å bidra til utvikling av digitale læringsressurser som kunne støtte denne overgangen.

En bieffekt var også at prosjektets arbeid kunne bidra til sykepleierundervisernes utvikling av pedagogisk kompetanse i bruk av digitale læringsressurser i begge fagmiljøene.

Gjennom en kartleggingsundersøkelse blant sykepleierstudentene $(\mathrm{n}=107)$ ved de to campusene våren 2016 konkluderte prosjektgruppa med at fokuset for prosjektet skulle rettes mot forberedelsesfasen før praksisstudiene i grunnleggende sykepleie i kommunehelsetjenesten, første studieår.

\section{Skal få kompetanse}

I gjeldende rammeplan for sykepleierutdanning (1) er det beskrevet at: 
«Formålet med veiledede praksisstudier er at studentene skal oppnå optimal yrkeskompetanse for å kunne møte pasientens og samfunnets behov for sykepleie som en del av et samlet behandlingstilbud» (s. 11).

I praksisstudier skal studentene utvikle sin kompetanse gjennom møter med pasienter. I ulike situasjoner vil de opparbeide kommunikasjonsferdigheter, øve på praktiske ferdigheter og ta del i et praksisfellesskap (2). Veiledning og vurdering av praksisstudiene gjennomføres mellom sykepleierstudent, praksisveileder og lærer fra utdanningsinstitusjonen (3). Disse aktørene har også vært utgangspunktet i utformingen av den digitale læringsarenaen Praksisportalen.

\section{Hva er Praksisportalen?}

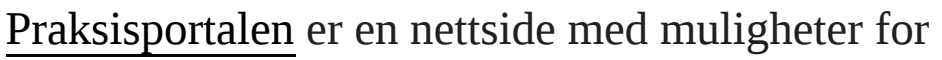
fleksible læringsforløp med fire moduler som har ulike fokus. Visuelle virkemidler som videoforelesninger, videosnutter med fiktive eksempler og et virtuelt pasientrom etterfølges av refleksjonsspørsmål og oppgaver. Helheten i de ulike modulene skal bidra til en god forberedelse for sykepleierstudenten i første studieår på ulike plan.

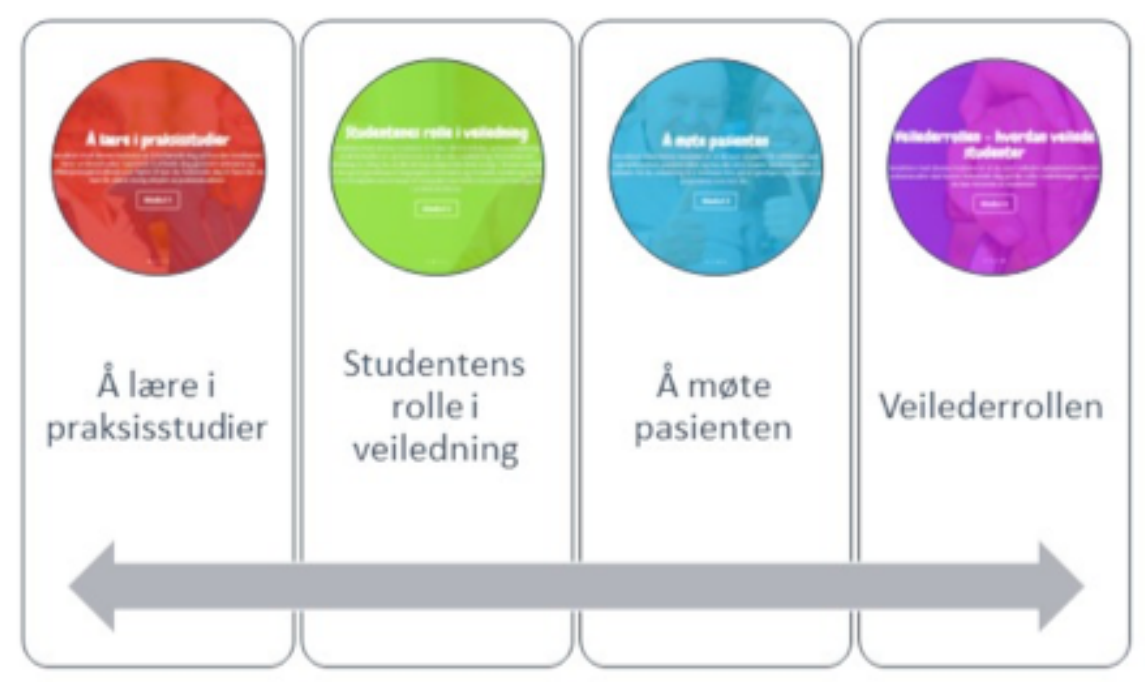

FIRE MODULER: Praksisportalen har fire moduler med forskjellig tema. (Illustrasjon: Praksisportalen) 
Digitale læringsarenaer er ikke nytt i

utdanningssammenheng, ett eksempel kommer fra

England hvor en liknende nettstøttet ressurs hadde som

formål å «sette i gang» studentene i deres

praksisstudier (4). Vi er ikke kjent med liknende

digitale læringsressurser ved sykepleierutdanninger i

Norge, men det er mulig at det finnes liknende

ressurser i lukkede læringsarenaer ved

utdanningsinstitusjonene. At Praksisportalen er

fleksibel og åpen har vært av stor betydning for

prosjektgruppa - både med tanke på praksisveileders

tilgang til læringsinnholdet, men også for å bidra til

$ø k t$ delingskultur på tvers av utdanningsinstitusjonene.

$\AA$ A bruke digitale verktøy i kombinasjon med

tradisjonell veiledning og undervisning ansikt-til-

ansikt, omtales ofte som blended learning (5). Blended

learning innebærer at man på ulikt vis kan bruke

digitale arenaer i forberedelser, underveis og etter

fysiske veiledningsmøter. Praksisportalen med sin åpne og fleksible utforming kan brukes i en blended learning-tilnærming på ulike vis og vi vil beskrive konkrete eksempler.

\section{Hvordan bruke portalen?}

I praksisstudier vil mye av fokuset rettes mot utvikling av praktiske ferdigheter og samhandling med pasienten. Læring og mestring skjer gjennom å erfare ulike situasjoner og å bruke erfaringene for eksempel som utgangspunkt for refleksjon (2) og tilbakemelding fra veileder (6).

I modul 1, «Å lære i praksisstudier», gis studenten anledning til innsikt i hvordan læring skjer i praksisstudier og hvordan studenten skal forberede sin egen læring gjennom for eksempel å starte utformingen av personlige målsettinger. Studenten vil også bli utfordret gjennom refleksjonsspørsmål til å sette ord på egne forventninger og egne ressurser og utfordringer, noe vi har erfart at mange studenter sliter med. 
I modul 2, «Studentens rolle i veiledning», vil

studenten kunne forberede seg på sin rolle i

veiledningssituasjoner. I modulen gis det eksempel på

hvordan veiledning kan foregå. Ulike

vurderingsformer introduseres og hva veiledning i

praksisstudier innebærer presenteres kort. Ulike

videoer retter tydelige forventninger til studenten som

en aktiv part i veiledningsrelasjonen både til

praksisveileder og lærer.

Å forberede seg på å møte en virkelighet man ikke kjenner kan i mange tilfeller oppleves vanskelig eller til og med umulig. Sykepleierstudenter i første studieår er en heterogen gruppe med ulike erfaringer fra helsevesenet - gjerne sett fra ulike perspektiv.

\section{三 «Noen studenter har aldri vært innenfor dørene på et sykehjem eller et sykehus.»}

Noen studenter har aldri vært innenfor dørene på et sykehjem eller et sykehus, andre har hatt rolle som pårørende, pleieassistent eller lengre erfaring som fagutdannet. Det som for de aller fleste likevel er ukjent, er rollen som student i praksisstudiene.

Gjennom modul 3, «Å møte pasienten», har målet vært å utjevne forskjellene mellom de ulike studentenes tidligere erfaringer. I et interaktivt pasientrom ved et sykehjem får studentene mulighet til å møte en fiktiv pasient i trygge omgivelser. Her gis det mulighet for å utforske og reflektere over viktige aspekter i sykepleie gjennom å trykke på ulike symboler (trykkpunkter) som inneholder tekst, filmsnutter og lydfiler. De ulike trykkpunktene skal være med på å gi studentene nye dimensjoner ved det komplekse møtet med pasienten og bidra til nødvendige forberedelser til praksisstudiene. 


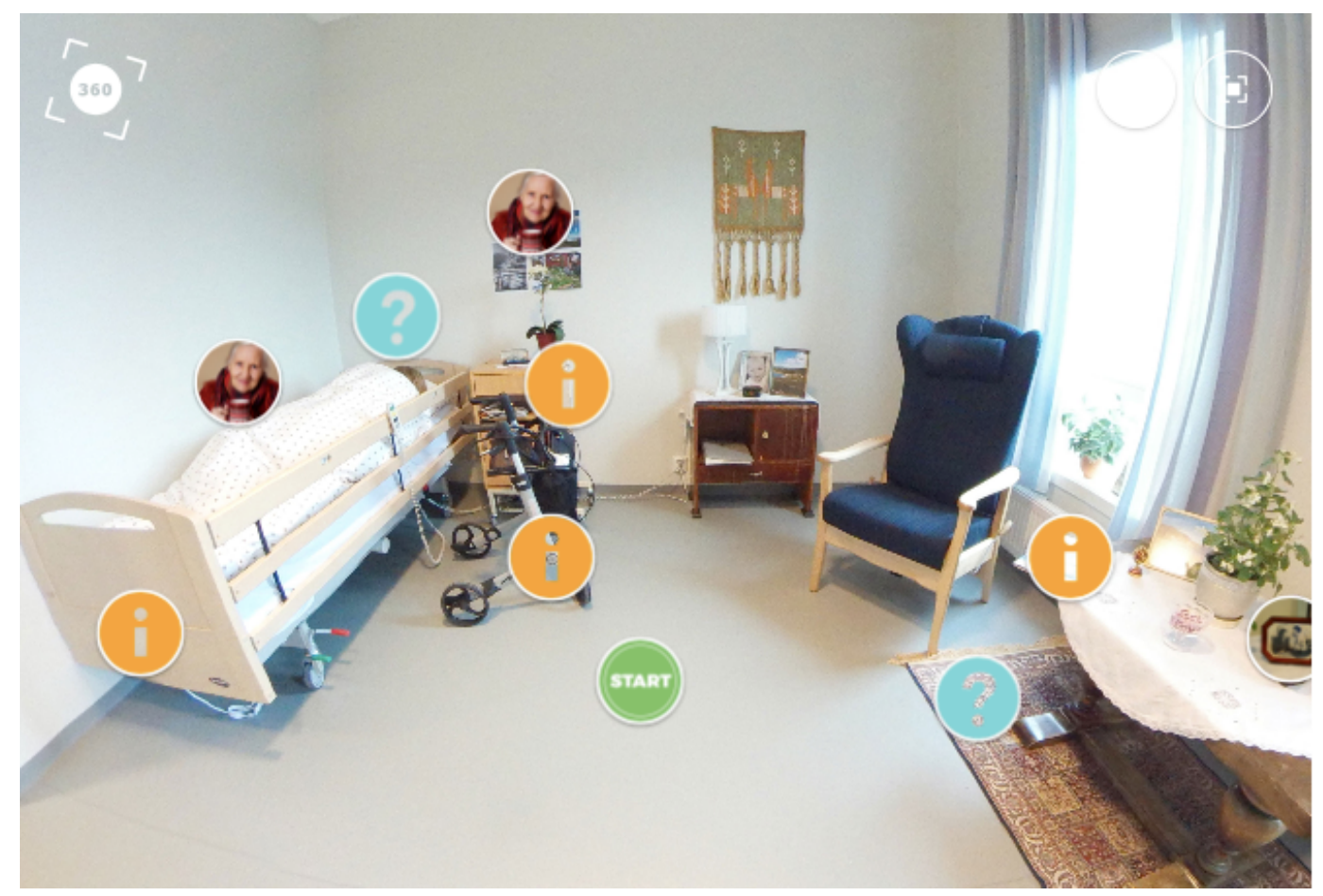

PASIENTROM: I et interaktivt pasientrom kan studenten trykke på ulike symboler som inneholder tekst, filmer og lyd. (Illustrasjon: Praksisportalen)

Modul 4, «Veilederrollen», er først og fremst rettet mot praksisveiledere. Samtidig mener vi at det er positivt at studentene har mulighet til å sette seg inn i hva som forventes av praksisveilederen og hva veiledning i praksis bør innebære. Gjennom både det veiledningsfaglige innholdet i modulen og veiledningseksempelet kan studenten bli bevisst på hvordan dens eget veiledningstilbud oppleves. Kanskje kan læringsinnholdet være opphav til en diskusjon mellom student, praksisveileder og lærerveileder omkring organisering av veiledning og hvordan praksisveileders rolle og ansvar er forventet å være?

\section{Egen modul for veiledere}

Gjeldende rammeplan for sykepleie (1) krever at studenter i praksisstudier får «jevnlig veiledning, oppfølging og vurdering». En rapport fra Norsk Sykepleierforbund (7) viser at viljen til å gi gode og veiledende praksisstudier i kommunehelsetjenesten er stor, men at rammebetingelsene ikke legger til rette for veiledning. 
Rapporten beskriver både mangel på formell veiledningskompetanse blant praksisveilederne og i tillegg mangel på avsatt tid til praksisveiledning. Det legges også lite til rette for veiledningsfaglig oppdatering (7).

Som beskrevet er mye av innholdet i Praksisportalen rettet direkte mot studentene og deres forberedelser til praksisstudiene. Modul 4 i Praksisportalen er laget for praksisveileder som et bidrag til faglig utvikling. I likhet med at studentene får innsikt i forventninger til praksisveileder, vil også praksisveilederens innsikt i studentrettet innhold kunne få betydning for bevissthet omkring forventninger til studentens forberedelser før praksisperioden.

Praksisveileder vil i forkant av praksisperioden ha anledning til å sette seg inn i for eksempel hvordan studenten bør og kan skrive personlige målsettinger eller hva praksisveileder kan forvente at studenten bringer med seg til veiledning.

Selv om det formelle ansvaret for at studenten stiller forberedt til praksisstudiene ligger hos utdanningsinstitusjonen, kan praksisveileders kjennskap til studentens forberedelser virke motiverende og læringsfremmende for studenten. Ved å gjennomgå de studentrettede modulene i Praksisportalen vil praksisveileder lettere kunne bidra til å skape sammenheng for studenten. Et eksempel er at praksisveileder i veiledningsmøter blir med studenten inn i det virtuelle pasientrommet og reflekterer sammen med studenten. Oppdagelser fra det virtuelle rommet kan også, med veileders bidrag, settes i sammenheng med de reelle pasientmøtene som venter studenten eller noe den allerede har erfart.

\section{Nyttig for lærere}


På sykepleierutdanningen ved UiT er læreren i en veiledningsfunksjon både på skolen og i praksisfeltet. I emneplanen for første studieår står det at lærerveileder skal «veilede studenten i generell sykepleie og sykepleie knyttet til akutt og kronisk syke, og i samtaler rettet mot konkrete læresituasjoner» (8).

Også lærerveileder har mange muligheter for å tilrettelegge for læring ved anvendelse av modulene i Praksisportalen. Det vil i stor grad være opp til den enkelte veileder å bestemme rekkefølgen på studentenes aktiviteter i portalen.

Studenten kan selvsagt også legge opp en egen rekkefølge med utgangspunkt i eget behov. Vi tror lærerveileders bruk og omtale av Praksisportalen danner en viktig forutsetning for både studentens og praksisveilederens bruk.

Lærerveileder kan på den ene siden bruke Praksisportalen i tilrettelegging for studentens forberedelser, for eksempel i møter med studentene i forkant av praksisstudiene eller i praktisk ferdighetstrening som grunnlag for refleksjon, tilbakemelding, læring og mestring. På den andre siden viser rammeplan for sykepleierutdanning til utdanningsinstitusjonens ansvar for «kompetansebygging innen veiledning». Selv om ansvaret ikke ligger på den enkelte lærerveileders bord kan den som er kontaktperson ut mot praksisfeltet bruke Praksisportalen som et grunnlag for forberedelse og dialog med praksisplassens veiledere før, under og etter studentenes praksisstudier.

\section{三 «Det virtuelle pasientrommet kan brukes som utgangspunkt for studentens refleksjon over egen praksis.»}


Underveis i praksisperioden vil læreren kunne bruke Praksisportalen i veiledningsmøter med studenter. Studentene kan forbereder seg til veiledningsmøtet gjennom å se videosnutter. Det virtuelle pasientrommet kan brukes som utgangspunkt for studentens refleksjon over egen praksis. Kanskje kan veiledningsmøte med det virtuelle pasientrommet skje som en felles aktivitet med både praksisveileder og lærerveileder til stede?

Også etter praksisperioden kan portalen benyttes som et virkemiddel for å skape refleksjon over læringsutbytte og veiledning fra praksisperioden. Det kan for eksempel gjøres ved å sammenlikne forventninger til praksis med merforståelse etter praksisstudienes avslutning. Da kan man også finne ut om studenten og eller praksisveileder forstår innholdet på samme måte som før praksisstudiene.

\section{Tilbakemeldinger så langt}

Åtte studenter prøvde ut Praksisportalen våren 2017, med evaluering før og etter utprøvingen. Studentene skulle først svare på spørsmål uten å ha vært i Praksisportalen. De ble deretter bedt om å se videoene i modul 1, 2 og 4, svare på refleksjonsspørsmål og danne seg et helhetlig inntrykk av portalen før de til slutt evaluerte portalen i en ny questback. Modul 3 med det virtuelle pasientrommet var ikke ferdig da utprøvingen ble gjennomført. Tilbakemeldingene fra studentene var generelt positive, og filmatiserte rollespill ble ansett som særlig relevante og lærerike.

\section{三 «Filmatiserte rollespill ble ansett som særlig relevante og lærerike.»}


Praksisplassene hvor studentene skulle utplasseres ble i forkant av pilotutprøvingen informert om

Praksisportalen. En uformell tilbakemelding fra praksisplassenes sykepleiere var at portalens innhold kunne danne grunnlag for faglige diskusjoner, spesielt i avdelingens forberedelser til å ta imot studenter. Sett i ettertid har manglende involvering av praksisfeltet vært en svakhet i prosjektet.

Også lærere ved sykepleierutdanningen har ved flere anledninger fătt informasjon om Praksisportalen. På bakgrunn av denne artikkelen håper forfatterne at flere utdanninger prøver ut og gir tilbakemeldinger på form og innhold.

\section{Veien videre}

I januar i år ble Praksisportalen publisert uten konkrete instrukser til fagmiljøene, verken i praksisfeltet eller utdanningsinstitusjonene. Studentene har i hovedsak mottatt informasjon gjennom læringsplattformen Canvas. En del lærere har henvist til portalen i møte med studenter, andre har i større forelesninger prøvd ut det virtuelle pasientrommet. Allikevel er det lite som tyder på at Praksisportalen har blitt tatt i bruk i større utstrekning.

Arbeidet med Praksisportalen har vært tidkrevende, men slik vi ser det gjenstår kanskje størstedelen av arbeidet. Implementering gjennom å bygge eierskap hos brukerne vil være avgjørende for at Praksisportalen ikke bare skal bli nok en ubrukt nettside. 
Gjennom idémyldring og erfaringsdeling i og på tvers av utdanningene kan fokuset rettes mot hvordan Praksisportalen kan skape både faglig og pedagogisk merverdi for studenter, praksisveiledere og lærerveiledere. Praksisportalen må tas systematisk i bruk som et bidrag i å styrke studentens utbytte av praksisstudiene. Det er ikke Praksisportalen i seg selv som vil skape læring, men heller hvordan den blir brukt (9).

For fremtiden er målet at Praksisportalen utvides med flere moduler for andre og tredje studieår, og med bidrag fra flere sykepleierutdanninger i Norge. Kanskje kan det også legges til rette for interaksjon og samhandling mellom studenter, praksisveileder og lærerveiledere i fremtidige versjoner av portalen. Allerede har det blitt diskutert mulige fokusområder videre, blant annet å styrke forberedelser til praksisstudier i psykisk helse. Nasjonalt samarbeid vil ikke bare styrke kvalitet i praksisstudier, men også bidra til å styrke kvalitet i høyere utdanning jf. stortingsmeldingen Kultur for kvalitet i høyere utdanning (10).

\section{Referanser}

1. Kunnskapsdepartementet. Rammeplan for sykepleierutdanning. Oslo: Kunnskapsdepartementet; 2008.

2. Bjørk IT, Bjerknes MS. Å lære i praksis: en veiviser for studenten. Oslo: Universitetsforlaget; 2003.

3. Jonsmoen KM, Greek M. Praksisboka: slik lykkes du i praksisstudiene. Oslo: Gyldendal Akademisk; 2016.

4. Reynolds S, Kaur R. Supporting student nurses with an online induction. Nursing times. 2016;112(45/46):13-15. 
5. Margaryan A, Collis B, Cooke A. Activitybased blended learning. Human Resource

Development International. 2004;7(2):265-74.

6. Hattie J, Timperley H. The Power of Feedback.

Review of Educational Research. 2007;77(1):81-112.

7. Norsk Sykepleierforbund. Stor vilje - lite ressurser. En kartlegging av rammebetingelser for veiledning av sykepleierstudenter $\mathrm{i}$ kommunehelsetjenesten. Oslo: Norsk Sykepleierforbund; 2018.

8. Institutt for helse- og omsorgsfag. Bachelorutdanning i sykepleie. Emneplan for 1. studieenhet. Tromsø/Hammerfest: Institutt for helseog omsorgsfag, Universitetet i Tromsø; 2017.

9. Bergdahl N, Fors U, Hernwall P, Knutsson O. The use of learning technologies and student engagement in learning activities. Nordic Journal of Digital Literacy. 2018;13(02):113-30.

10. Meld. St. nr. 16 (2016-2017). Kultur for kvalitet i høyere utdanning. Oslo:

Kunnskapsdepartementet; 2017. 